\title{
AGE-DEPENDENT CHANGES OF THE CHEMICAL AND ENERGY CARCASS COMPOSITION IN DUCKS DURING THE FIRST EIGHT POST-HATCHING WEEKS
}

\section{A. HOLUB ${ }^{1}$, EVA BARANYIOVÁ ${ }^{2}$ and EMILIE PONIŽILOVÁ ${ }^{3}$}

${ }^{1}$ Institute of Animal Physiology, Slovak Academy of Sciences, 04001 Košice, 2 Dedartment of Physiology, University of Veterinary Science, 61242 Brno and ${ }^{3}$ Department of Veterinary Prevention, University of Agriculture, 61300 Brno

Received November 15, 1988

$A b s t r a c t$

H $\circ 1 \mathrm{ub}$ A., Eva B a r a y $\mathrm{i} \circ \mathrm{v}$ and $E \mathrm{~m}$ i 1 i e

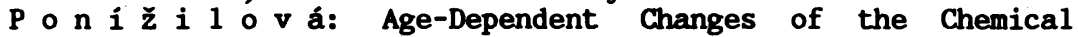
and Energy Carcass Composition in Ducks During the First Eight Post-Hatching Weeks. Acta vet. Brno, 58, 1989:3-16.

Ninety White Peking ducks were killed at weekly intervals from hatching to $56 \mathrm{~d}$ of age to assess age-dependent changes in their carcass mass and chemical and energy composition. During this period the carcass mass increased 50 times, water content 39 times, protein content 58 times, fat content 100 times and the gross energy (GE) content 76 times. The deposition of all the components under study was most intense in the 2nd week. The carcass hydration decreased with age more abruptly than in the domestic fowl. The protein concentration rose, after an initial decrease, to almost twice the original value by $42 \mathrm{~d}$ and then moderately decreased. The fat concentration rose up to $21 \mathrm{~d}$, equalled the protein concentration by $35 \mathrm{~d}$ and then became lower again. The energy density of the tissues changed similarly to the fat energy concentration: the contribution of fat to the retention of GE did not exceed $60 \%$, thus being smaller than, e.g., in an average man. The performance at GE accumulation averaged $4.83 \mathrm{~W} . \mathrm{kg}^{-0.75}$; in the $2 \mathrm{nd}$ week, when it was lowest, and also in the $3 \mathrm{rd}$ week it was so high $(11.1 \mathrm{W.kg}-0.75)$ that it exceeded the limit envisaged by $K i r k w 00 d$ and $W$ e b s e r (1984).

Duck, age-dependent changes, protein, fat, water, gross energy, carcass

Commercially important characteristics of slaughter ducks and the narrow spectrum of factors related to the profitability of duck meat production have recently been the subject of numerous studies ( $P$ i $n g$ e 1 et al. 1969; $\mathrm{R} \mathrm{ud} \circ 1 \mathrm{ph}$ and $\mathrm{H} \circ \mathrm{p} \mathrm{pe} 1972 ; \mathrm{C} 1$ a $\mathrm{t} \circ \mathrm{n}$ et al. 1974; 
$\mathrm{H} u \mathrm{~d} s \mathrm{k} \dot{\mathrm{y}}$ and $\mathrm{M}$ a c há $1 \mathrm{ek}$ 1978; C 1 a y $\mathrm{t} \circ \mathrm{n}$ and $\mathrm{P}$ o w e 11 1979; $K$ o č $i$ et al. 1982; L e e s o n et al. 1982; H u d s $k \dot{y}$ and $\zeta$ e $r \vee$ e $n \dot{y}$ 1983). Interest has also been centered upon the growth of ducks ( $\mathrm{L}$ e $\mathrm{c} 1 \mathrm{e} \mathrm{r} q$ and de $\mathrm{C}$ a r v i $11 \mathrm{e}$ 1972; S w t 1 a n d 1980a; K n i ž e t o vá et al. 1988), its allometric parameters (M a h e $1 \mathrm{k}$ a 1964, 1973; S w a t 1 a nd 1980b; B a u m g a t n e r et al. 1982), some muscle groups ( $\mathrm{w}$ a $t 1$ a $\mathrm{n} d$ 1980c, 1981) and upon fat deposits ( $\mathrm{v}$ a $\mathrm{n}$ s 1972).

Age-dependent changes of the chemical composition of the duck carcass, on the other hand, have received relatively little attention ( $\mathrm{a} r$ a$\mathrm{n}$ y $\mathrm{i} \circ \mathrm{v}$ á et al. 1980; $\mathrm{H} \circ 1 \mathrm{u} \mathrm{b}$ et al. 1988). In this respect only some organs such as the gastrointestinal tract and the liver have been described ( $\mathrm{a} \mathbf{r}$ a $\mathrm{n}$ y $\mathrm{i}$ o $\mathrm{v}$ a et al. 1983). At present it is therefore not possible to define ducks, with reasonable reliability, as energy concentrators or protein transformers. To fill this gap in our knowledge the present study was designed.

\section{Materials and Methods}

A total of 90 White Peking ducks aged 1 to $56 \mathrm{~d}$ were included in the experiment. They were reared in rearing houses equipped with heaters under which the temperature was about $30{ }^{\circ} \mathrm{C}$ and the birds were free to choose the environmental temperature. They had free access to water and were fed commercial starters VKCH 1 and VKCH 2.

The measurements were carried out at weekly intervals on groups of 10 ducks each. The birds were weighed and killed by asphyxiation without bleeding. After the feathers, gastrointestinal tract and the yolk sac were removed, the carcasses were weighed and processed in a blander. After mixing, samples were taken and dried to constant mass at 90 to $95{ }^{\circ} \mathrm{C}$ for $24 \mathrm{~h}$. Total nitrogen and fat content of the dry matter were determined using two samples for each analysis. Total nitrogen was measured by a micromethod (C O n w a $\mathrm{y}$ 1957) and fat by $24 \mathrm{~h}$ petroleum-ether extraction

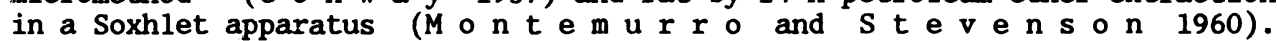
Water content was determined from the difference between wet mass and dry matter. The same procedure was used in our previous studies to determine the chemical composition of the gastrointestinal tract, liver (B a r a n $\mathrm{i} \circ \mathrm{v}$ a et al. 1983) and feathers ( $\mathrm{H} \circ \mathrm{l}$ u b et al. 1988). Gross energy (GE) of the carcasses (including the gastrointestinal tract, liver and feathers) was calculated from their content of protein (23.9 $\left.\mathrm{kJ} \cdot \mathrm{g}^{-1}\right)$, fat $\left(39.4 \mathrm{~kJ} \cdot \mathrm{g}^{-1}\right)$ and occasionally saccharides $\left(17.5 \mathrm{~kJ} \cdot \mathrm{g}^{-1}\right)$. In contrast to liver glycogen, the GE of muscle glycogen and blood glucose was not included in the computation because the evidence available did not allow us its reliable quantification. Nevertheless, the concentration of these saccharides in the muscles and blood was, no doubt, so low (B a r a n y $\mathrm{i} \circ \mathrm{va}$ and $\mathrm{H} \circ \mathrm{lub} 1969,1971$ ) that its contribution to total GE of the carcass did not exceed $1 \%$ in any of the duck age categories under study and therefore could not significantly affect out results.

Relative growth of the carcass mass and its water, protein, fat and GE content were calculated according to the formula $\frac{100\left(y_{2}-y_{1}\right)}{0.5\left(y_{1}+y_{2}\right)}$ (B $r \circ d y$ 1945). The increases of water, protein, fat and $\mathrm{GE}$ were also assessed relative to the carcass mass. 


\section{Results}

The live body mass of the ducks increased 45 times, by $2360 \mathrm{~g}$, between 1 and $56 \mathrm{~d}$ (Table 1 ). The mean weekly increase was $42.9 \mathrm{~g} \cdot \mathrm{d}^{-1}$, the lowest increase being recorded in the 1st week and the highest in the 5 th week (it was then tenfold higher than in the 1st week) (Fig. 1).

Table 1

Changes in the live body mass and carcass mass in ducks during the first 8 post-hatching weeks

\begin{tabular}{lcc}
$\begin{array}{c}\text { Age } \\
\text { d }\end{array}$ & Live body mass & Carcass mass \\
\hdashline 1 & g & g \\
7 & $54 \pm 2$ & $44 \pm 2$ \\
14 & $93 \pm 2$ & $83 \pm 2$ \\
21 & $305 \pm 12$ & $273 \pm 11$ \\
28 & $635 \pm 16$ & $569 \pm 4$ \\
35 & $1001 \pm 47$ & $919 \pm 45$ \\
42 & $1451 \pm 38$ & $1282 \pm 43$ \\
49 & $1755 \pm 47$ & $1652 \pm 47$ \\
56 & $2135 \pm 54$ & $1968 \pm 60$ \\
& $2414 \pm 65$ & $2199 \pm 86$
\end{tabular}

During the same period the carcass mass rose 50 times, by $2155 \pm 86 \mathrm{~g}$, i. e. relatively more than the live body mass (Table 1). During two 14-d periods, week 4 plus week 5 and week 5 plus week 6 , i. e. each time during a quarter of the period under study, it rose by a third and by the end of the three weeks by as much as a half. Its weekly increase averaged $39.2 \mathrm{~g} \cdot \mathrm{d}^{-1}$, being lowest in the 1st week and highest in the 5 th week (it was then as many as 8 times higher than in the 1st week) (Fig. 1). The contribution of the carcass mass to the live body mass averaged $89.7 \%$. It changed with age: it was lowest after hatching, rose steeply up to $7 \mathrm{~d}$ and then showed only 
a moderate upward trend, with some fluctuations, peaking on $42 \mathrm{~d}$ (Fig. 2).

Water was the chemical component that contributed most to the carcass mass. Its quantity rose during the observation period more than 39 times, by $1230 \pm 39 \mathrm{~g}$ ( Table 2). Similarly to the carcass mass, it did not increase evenly with age: it rose by a third during week 4 plus week 5 as well as during week 5 plus week 6 and by a half during these three weeks taken together. Its weekly increase averaged $22 \mathrm{~g} \cdot \mathrm{d}^{-1}$, being lowest in the 1 st week and highest in the 4 th and 6th weeks (Fig. 3). The hydration of the carcass averaged $64.1 \%$. It was highest at $1 \mathrm{~d}$ and then declined with advancing age, falling to less than 4 fifths of the initial concentration (Fig. 4).

Table 2

Changes in the quantities of water, protein, fat and GE in ducks during the first 8 post-hatching weeks

\begin{tabular}{|c|c|c|c|c|}
\hline $\begin{array}{l}\text { Age } \\
\text { d }\end{array}$ & $\begin{array}{c}\text { Water } \\
\mathbf{g}\end{array}$ & $\begin{array}{c}\text { Protein } \\
\mathrm{g}\end{array}$ & $\begin{array}{c}\text { Fat } \\
\mathrm{g}\end{array}$ & $\begin{array}{l}\text { GE } \\
\text { MJ }\end{array}$ \\
\hline 1 & $32 \pm 1$ & 7 & 4 & 0.3 \\
\hline 7 & $57 \pm 2$ & 12 & 6 & 0.5 \\
\hline 14 & $193 \pm 7$ & 35 & 29 & 2.0 \\
\hline 21 & $360 \pm 10$ & 78 & 91 & 5.8 \\
\hline 28 & $571 \pm 28$ & 167 & 165 & 10.6 \\
\hline 35 & $755 \pm 26$ & 242 & 268 & 16.5 \\
\hline 42 & $980 \pm 28$ & 368 & 282 & 20.0 \\
\hline 49 & - & 394 & 346 & 23.2 \\
\hline 56 & $1262 \pm 39$ & 421 & 376 & 25.1 \\
\hline
\end{tabular}

The actual protein quantity increased almost 58 times (Table 2). The total amount of protein deposit was $414 \pm 13 \mathrm{~g}$; most of it was deposited in the 5 th and 6 th weeks (almost a half) and during the 3rd to the 6th weeks (almost three quarters). The weekly protein deposit averaged $7.5 \mathrm{~g} \cdot \mathrm{d}^{-1}$; 


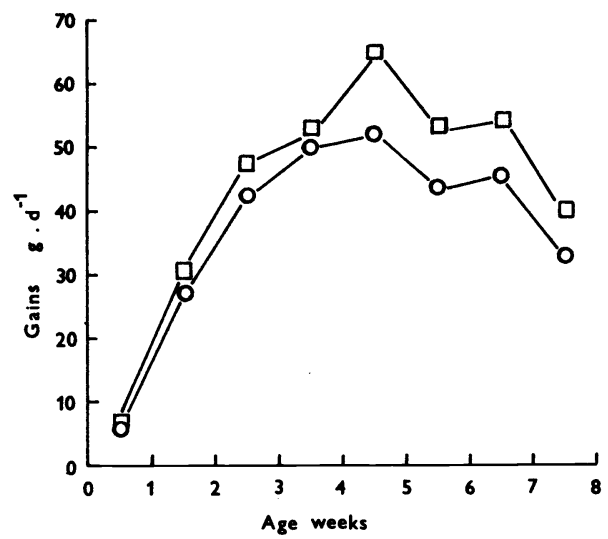

Fig. 1. Daily gains in the contribution of live ( $\square$ ) and carcass (O) mass in ducks during the first 8 post-hatching weeks.

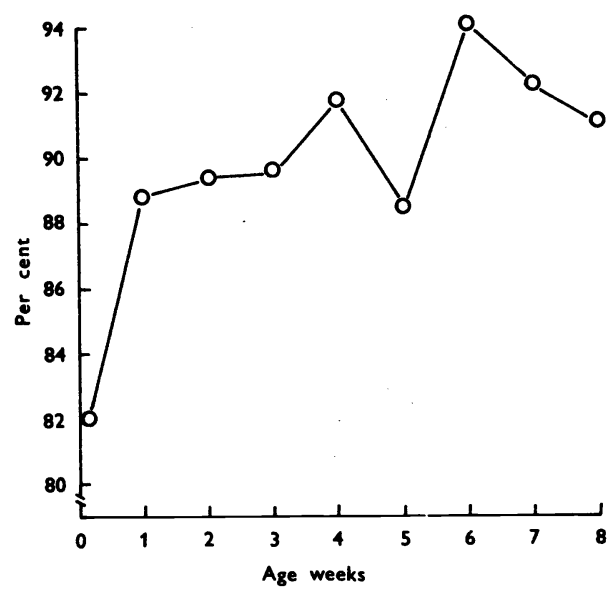

Fig. 2. Changes in the contribution of the carcass mass to the live body mass of ducks during the first 8 post-hatching weeks.

it was lowest in the 1st week and highest in the 4 th and 6 th weeks, i. e., it changed similarly to the water content (Fig. 3 ). The carcass protein concentration averaged $17.3 \%$. At $1 \mathrm{~d}$ of age it was near the mean value, declined up to $14 \mathrm{~d}$, increased to almost twice as much by $42 \mathrm{~d}$ and then showed a moderate decline up to $56 \mathrm{~d}$ (Fig. 4).

The actual carcass fat mass increased more than hundredfold, thus showing a relatively higher rise than any of the remaining components under study (Table 2). The total fat deposit was $2373 \pm 14 \mathrm{~g}$. After an abrupt rise during the first two post-hatching weeks the fat deposition was highest in the $3 \mathrm{rd}$ to 7 th weeks ( 8 to 9 tenths of the total deposit). The weekly fat deposit averaged $6.7 \mathrm{~g} \cdot \mathrm{d}^{-1}$. In the 5 th week, however, it was almost fiftyfold higher than in the 1st week. Its variation with age was therefore considerable (Fig. 3). This phenomenon became apparent also in the fat concentration. This increased to more than twice the post-hatching value by $21 \mathrm{~d}$ and then continued at approximately the same level. By the end of the 2nd week it was lower than the protein concentration, and after equalling the latter by $35 \mathrm{~d}$, became lower again (Fig. 4).

The amount of carcass GE increased 76 times, by $24.7 \pm$ \pm 0.9 MJ, during the period under study (Table 2); the 


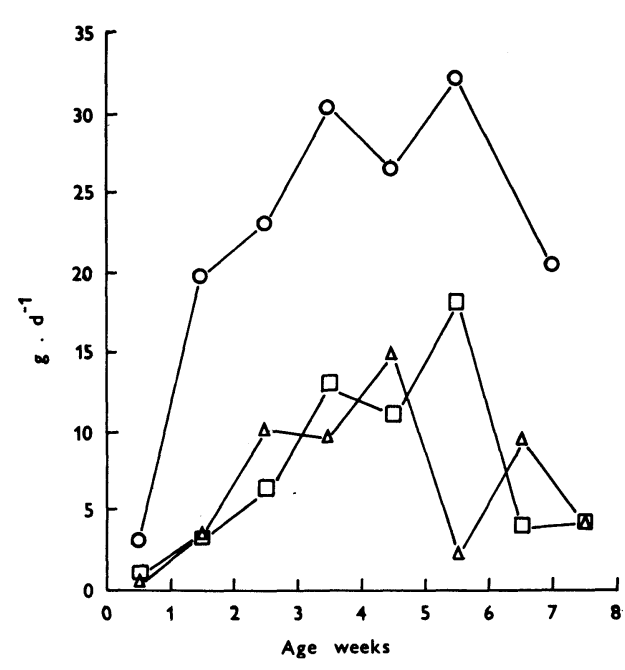

Fig. 3. Daily gains of water $(0)$, protein $(\square)$ and fat $(\Delta)$ of uucrs during the first 8 post-hatching weeks.

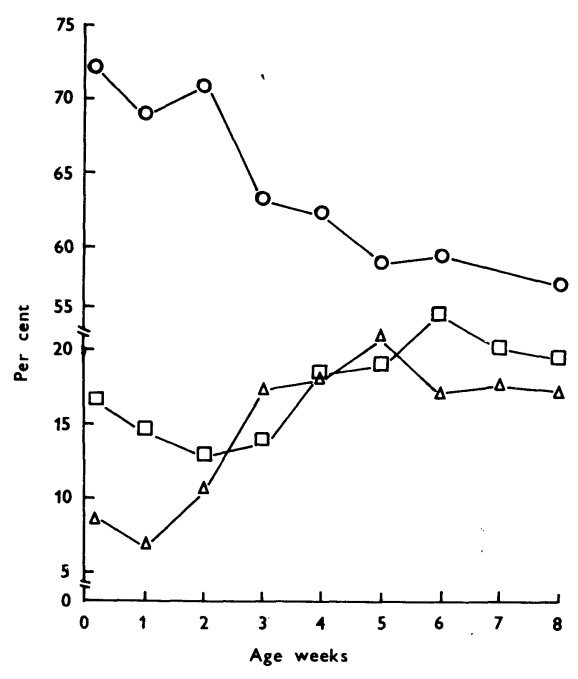

Fig. 4. Changes in proportions of water (0), protein ( $\square$ ) and fat $(\Delta)$ in the live body mass of ducks during the first 8 posthatching weeks.

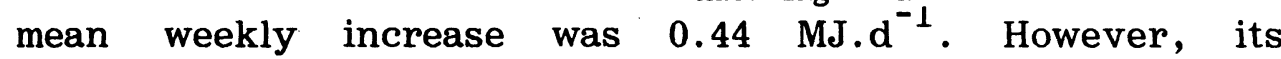
retention varied with age: it was minimal in the 1st week, rose by almost a quarter of its total 8-week quantity in the 5 th week and then declined almost equally abruptly during the following 3 weeks (Fig. 5).

There were considerable differences in the GE deposition between. the individual chemical carcass components. It rose mostly in lipids, by $14.8 \mathrm{KJ}$, the mean increase there being $0.27 \mathrm{KJ} . \mathrm{d}^{-1}$. After an abrupt rise it remained practically unchanged from the $3 \mathrm{rd}$ to the 7 th week, exceeding the 1st-week accumulation more than 40 times. The deposit of $\mathrm{GE}$ in the non-fat carcass mass amounted

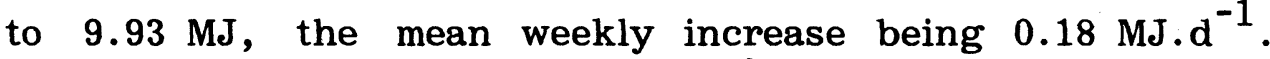
Thus the GE increase in the non-fat carcass mass was more than one third lower than in the lipids. It peaked in the 6 th week, by which time it exceeded the 1st-week minimal deposition 24 times (Fig. 5).

Relative increases in the parameters under study expressed in terms of Brody's formula (1945) were 192, 190, 193, 196 and 195 for carcass mass, water, protein, respecuvely. and $\mathrm{GE}$, resp. All of them also showed marked age changes. The values were highest in the 2nd week at which time the increases in carcass mass, water. protein 


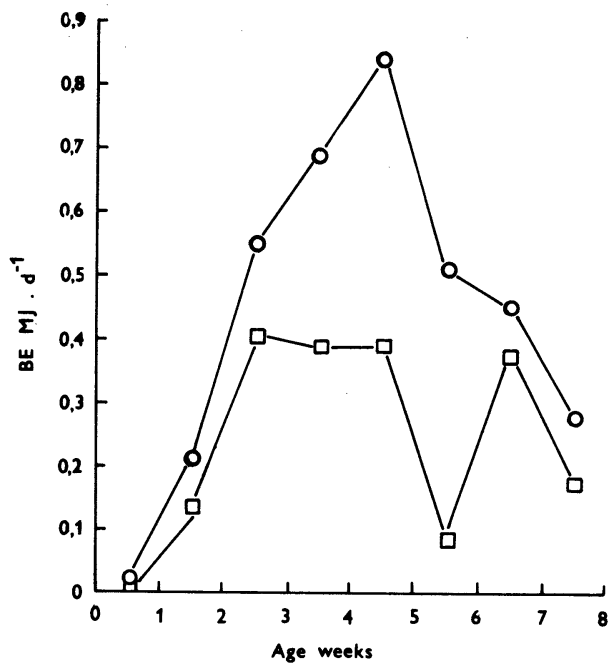

Fig. 5. Daily GE deposition in the bodies of ducks ( 0 ) and in the fat portion ( $\square$ ) of their carcasses during the first 8 post-hatching weeks. fat and GE were $9.7,4.3$, $13.9,16.3$ and 14.6 higher, respectively, than the increases recorded in the 8 th week (Table 3 ).

Expressed relative to carcass mass unit, the values for carcass mass, water, protein, fat and GE deposition yielded a different picture: the daily increases in carcass mass, water, protein and fat averaged $68,47,11$ and $10 \mathrm{~g} \cdot \mathrm{kg}^{-1} \cdot \mathrm{d}^{-1}$, respectively, and that in GE averaged $0.67 \mathrm{MJ} \cdot \mathrm{kg}^{-1} \cdot \mathrm{d}^{-1}$. Most of them peaked in the 2nd week. Afterwards the gains in carcass mass declined gradually with advancing age, falling to $10 \%$ of the peak value. A similar development was observed in chemical carcass components. Water and protein deposition declined gradually to 9 and $11 \%$, respectively, of the peak values. A somewhat

Table 3

Relative growth of the carcass mass, water, protein, fat and GE in duck carcasses during the first 8 post-hatching weeks

\begin{tabular}{lrrrrr} 
Week & Carcass mass & $\begin{array}{c}\text { Water } \\
\%\end{array}$ & Protein & Fat & GE \\
\hline 1 & & 56 & 48 & 40 & 42 \\
2 & 61 & 109 & 97 & 134 & 118 \\
3 & 107 & 61 & 77 & 110 & 98 \\
4 & 70 & 45 & 73 & 51 & 58 \\
5 & 47 & 28 & 37 & 47 & 43 \\
6 & 33 & 26 & 41 & 5 & 9 \\
7 & 25 & 25 & 7 & 21 & 15 \\
8 & 17 & & 7 & 8 & 8 \\
\hline $1-8$ & 11 & 190 & 193 & 196 & 195
\end{tabular}


different situation was recorded for fat and GE: their accumulation did not peak until the 3 rd week and then declined gradually to $9 \%$ of their maximum values (Table 4).

Table 4

Contributions of the daily gains in carcass mass, water, protein, fat and GE to the relative growth of carcass mass in ducks during the first 8 post-hatching weeks

\begin{tabular}{|c|c|c|c|c|c|}
\hline Week & $\begin{array}{l}\text { Carcass mass } \\
\mathrm{g} \cdot \mathrm{kg}^{-1} \cdot \mathrm{d}^{-1}\end{array}$ & Water & $\begin{array}{c}\text { Protein } \\
\mathrm{g} \cdot \mathrm{kg}^{-1} \cdot \mathrm{d}^{-1}\end{array}$ & Fat & $\cdot \mathrm{kg}^{-1} \cdot \mathrm{d}^{-1}$ \\
\hline 1 & 100 & 64 & 12.5 & 4.7 & 0.4 \\
\hline 2 & 152 & 110 & 18.0 & 18.5 & 1.19 \\
\hline 3 & 101 & 57 & 14.7 & 23.8 & 1.30 \\
\hline 4 & 67 & 40 & 17.2 & 12.8 & 0.92 \\
\hline 5 & 47 & 24 & 9.7 & 13.4 & 0.70 \\
\hline 6 & 36 & 22 & 12.2 & 1.4 & 0.35 \\
\hline 7 & 25 & 10 & 2.0 & 5.1 & 0.25 \\
\hline 8 & 16 & & 1.9 & 2.1 & 0.13 \\
\hline
\end{tabular}

\section{Discussion}

Birds differ considerably in their post-hatching development and growth mainly in dependence on the fact whether they are precocial, nidifugous or altricial, nidicolous ( R i c k l e f s 1979, 1983). N i e (1962) has distinguished four groups of precocials, two groups of altricials and one group each of semiprecocials and semialtricials. He has classified ducks within the second group of nidifugous birds where they belong on the basis of four out of the five criteria; the remaining criterion, however, would classify them within nidicolus birds. According to behavioural changes the post-hatching period is generally divided into 6 phases $(K \mathrm{u} \mathrm{h} 1 \mathrm{~m}$ a $\mathrm{n}$ 1909; $\mathrm{N}$ i c e 1943, 1962). The first phase occurs during incubation and the following two within $24 \mathrm{~h}$ of hatching 
( $\mathrm{N}$ i c e 1943, 1962). In our experiments ducks therefore underwent only the phases of locomotion, development of social interactions and juvenile sexual manifestations.

In our study, however, we used neither ethological nor morphological criteria because the growth of ducks can be measured reliably on the basis of changes in the parameters of mass and energy. In the first place we described therefore the accumulation of water and the retention of $\mathrm{GE}$.

The growth rate of the live body mass from the 3rd to the 5 th week was lower in our experiments than in those reported by $\mathrm{C}$ a $\mathrm{m} \mathrm{p} \mathrm{b} 1 \mathrm{l}$ et al. (1985). It was also lower than that reported by $\mathrm{H} \mathrm{u} \mathrm{d} \mathrm{s} \mathrm{k} \dot{\mathrm{y}}$ and Č e r v e n ý (1983) and than that listed in the relevant Czechoslovak standard (ON 466541 , 1979) but almost equalled the growth rate of the living body mass in ducks in a feeding experiment conducted in 1985 ( $\mathrm{K}$ a i s 1 e r and $\mathrm{H} \mathrm{l} \mathrm{u} \mathrm{b} \circ \mathrm{ck}$ a 1985ab) in the same enterprise where data used for the development of the aforementioned standard were previously obtained. On the other hand, our values were higher than those reported by $\mathrm{M} \mathrm{a} \mathrm{h} \mathrm{e} 1 \mathrm{k}$ a $(1964,1973)$. In spite of these differences it cannot be concluded that the birds used in our experiments showed variation from the growth characteristic of the Peking breed.

The carcass water content grew in the same way as in our previous experiments; in terms of actual content it increased 40 times. The carcass hydration, on the other hand, declined with advancing age, the highest rate of the decrease being recorded in the first 3 weeks. In general, however, the carcass hydration was lower and its decrease more abrupt than in the domestic fowl (B a r a n y i o vá et al. 1973).

During the post-ha+ching period the avian carcass is characterized by relative decrease not only of water but also of protein and by a concurrent relative increase of fat. In ducks, however, the concentration of protein is generally lower and that of fat higher than, e.g., in the domestic fowl and turkey. These differences have been accounted for by the fact that ducks consume relatively more nutrients and GE than the domestic fowl and turkey ( $\mathrm{S}$ i $\mathrm{r}$ e $\mathrm{g}$ a $\mathrm{r}$ and

$\mathrm{F}$ a $\mathrm{r}$ r e 11

$1980 \mathrm{ab}$ ).

Thus age-dependent changes in the relative carcass content of 
protein and fat in ducks were associated with feed consumption. More recently this statement was confirmed by the observation that restricted feed allowance resulted in a decreased proportion of fat in eviscerated duck carcasses. In ducks fed ad libitum, on the other hand, the proportion of fat was in agreement with that found in our experiments ( $\mathrm{C}$ a $\mathrm{m} \mathrm{p} \mathrm{b}$ e $1 \mathrm{l}$ et al. 1985).

In birds the potential of $\mathrm{GE}$ deposition is a function of both the living body mass ( $\mathrm{K} \mathrm{i} \mathrm{r} \mathrm{w}$ o o d and $\mathrm{W} e \mathrm{~b} s \mathrm{t}$ e 1984) and the relative fat accumulation ( $\mathrm{R} \mathrm{c} \mathrm{k} \mathrm{l} \mathrm{e} \mathrm{f} \mathrm{s} \mathrm{1974).} \mathrm{Although} \mathrm{this} \mathrm{phenomenon} \mathrm{is} \mathrm{less}$ marked in precocials than in altricials, the evidence from our experiments on ducks also showed that the increasing contribution of fat to their carcass mass resulted in increased energy density; adipose tissue contains 30 to $38 \mathrm{KJ} . \mathrm{kg}^{-1}$. It is therefore almost eightfold richer in GE than non-fat tissue having only 4.7 to $5.0 \mathrm{MJ.kg}^{-1}$ ( $\mathrm{G}$ a $\mathrm{r}$ o w 1982; $\mathrm{K}$ i $\mathrm{rk}$ w o $\mathrm{d}$ and $\mathrm{W}$ e b s t e r 1984).

In this connexion let us draw attention to the view that not even in growing birds the accumulation of metabolizable energy can exceed $790 \mathrm{~kJ} . \mathrm{kg}^{-0.75} \cdot \mathrm{d}^{-1} \quad(\mathrm{~K}$ i r k w o o d and $\mathrm{W}$ e b s t e r 1984); their performance cannot therefore be higher than $9.4 \mathrm{~W} . \mathrm{kg}^{-0.75}$.

Ducks in our experiments retained, on average, $0.55 \mathrm{MJ} . \mathrm{kg}^{-0.75} \cdot \mathrm{d}^{-1}$ during the first 8 post-hatching weeks; i. e., their performance was $6.3 \mathrm{~W}$. However, their GE deposition varied with age; in the 2nd and 3 rd weeks they retained 0.93 and $0.96 \mathrm{MJ}^{-\mathrm{kg}^{-0.75}} \cdot \mathrm{d}^{-1}$ and their performance was therefore 10.7 and $11.1 \mathrm{~W} . \mathrm{kg}^{-0.75}$, respectively. Since considering the objective of our study we did not think it necessary to distinguish between accumulated metabolizable energy and GE, it is obvious that the aforementioned maximum was exceeded. It was only at the end of the experimental period, i. e., in the 8 th week that the retention of GE by our experimental ducks decreased ninefold, declining to $0.15 \mathrm{MJ} . \mathrm{kg}^{-0.75} \cdot \mathrm{d}^{-1}$, i. e., to $1.7 \mathrm{~W} . \mathrm{kg}^{-0.75}$.

Although in our experimental ducks the amount of GE accumulated in the fat portion of the carcass was one third higher than that accumulated in the non-fat portion, the proportion of GE deposited in their lipids at 8 weeks of 
age was only $59.1 \%$, which is less than in an average man of $70 \mathrm{~kg}$ in body mass in whom two thirds of 559 or $660 \mathrm{MJ}$ are reportedly deposited in fat (A p f e $1 \mathrm{~b} \mathrm{a} \mathrm{u} \mathrm{m}$ 1978; G a $r$ r o w 1982).

\section{Věkové změny chemického složení a množství energie} $\mathrm{v}$ těle kachen $\mathrm{v}$ postinkubačním údobí

$\mathrm{Na} 90$ kachnách plemene bílého pekingského jsme od vylíhnutí do 56. dne $\mathrm{v}$ týdenních intervalech zjištovali hmotnost a chemickou i energetickou skladbu těla. Zjistili jsme, že za tuto dobu se hmotnost těla zvětšila 50krát; množství vody rostlo méně, jen $39 \mathrm{krát}$, bílkovin více, $58 \mathrm{krát,} \mathrm{tuků}$ a BE dokonce 100 př́ipadně 76krát. Nejintenzívnější depozici všech sledovaných komponent jsme zaznamenali $v$ týdnu druhém. Hydratace těla se $\mathbf{s}$ věkem snižovala prudčeji než $\mathrm{u}$ kurů. Koncentrace proteinů se po počátečním poklesu do 42. d zvýšila téměr̆ na dvojnásobek; nadále se však mírně snižovala. Koncentrace lipidů do 21. d stoupala, ve 35. d se vyrovnala bílkovinám, ale $u$ kachen vyšších věkových kategorií byla opět nižší. Energetická densita tkání těla se měnila obdobně jako koncentrace tuků. Jejich podíl na retenci $\mathrm{BE}$ nepřekročil $60 \%$. Byl tudíž menší než napr̆. u průměrného člověka. Průměrný výkon při akumulaci energie $B E$ byl roven $4.83 \mathrm{~W} . \mathrm{kg}^{-0,75}$; ve druhém týdnu, kdy byl maximální, ale i ve třetím, byl však tak velký, že dosahoval $11,1 \mathrm{~W} \cdot \mathrm{kg}^{-0,75}$; presahoval tedy limit předpokládaný Kirkwoodem a Websterem (1984).

Возрастные изменения химического состава

и количества энергии в теле уток

в постинкубационный период

У 90 Уток белой пекингской породы со дня вылупливания до 56 суток определяли в недельных интервалах массу и химический и энергетический состав тела. Было установлено, что в течение указанного периода масса тела увеличилась в 50 раз, количество воды увеличивалось в меньшей степени, лишь в 39 раз, белков - больше - в 58 раз, жиров и ВE даже В 100 или 76 раз. Самое интенсивное отложение всех исследуемых компонентов наблюдалось в течение второй недели. Гидратация тела 
С возрастом понихалась более стремительно чем Y курицы. Концентрация протеинов после. первоначального понихения до 42 суток увеличилась почти в два раза и в дальнейшем незначительно понихалась. Концентрация липидов до 21 дня увеличивалась, на 35 сутки равнялась белкам, но У уток более поздних возрастных категорий она была опять-таки более низкой. Эне ргетическая плотность тканей тела менялась аналогично концентрации жиров. Их дола в задержке ВE не превышала 60 \%. Она была, 'лледовательно, меньше доли, например, обыкновенного человека. Средняя интенсивность аккумулирования энергии ВЕ равнялась 4,83 Вт.кг ,75; на второй неделе она достигла максимального уровня, однако на третьей неделе она была настолько большой, что достигала 11,1 Вт.кг-0,75 выходя, следовательно, за пределы, предполагаемые Кирквудом и Вебстером (1984).

References

APFELBAUM, M.: Adaptation to changes in caloric intake. Proc. Fed. Nutr. Soc., $\underline{2}$, 1978: 543 - 559

BARANYIOVÁ, E. - HOLUB, A.: Age changes of liver and muscle glycogen content of ducklings in the first two months of life. Acta vet. Brno, 40, 1971: $273-278$

BARANYIOVÁ, E. - HOLUB, A.: Age changes of blood and plasma glucose levels in ducklings. Acta vet. Brno, 38, 1969: $497-500$

BARANYIOVÁ, E. - HOLUB, A. - SMRČKOVÁ, M. - YAHIA, M. H. - PONIŽILOVÁ, E.: Body hydration changes in ducks during the first two months of life. Acta vet. Brno, 42, 1973: 243 - 247

BARANYIOVÁ, E. - HOLUB, A. - PONIŽILOVÁ, E.: Age-dependent changes in body composition of ducks in the postincubation period. Inter. Union Physiol. Sci. XIV, XXVIII Inter. Congr. Budapest, 1980, p. 312

BARANYIOVÁ, E. - HOLUB, A. - PONIŽILOVÁ, E.: Changes in the mass and chemical composition of the gastrointestinal tract and liver of ducks in the first two months after hatching. Acta vet. Brno, 52, 1983: 39 $-47$

BAUMGARTNER, J. - ILLES, V.. - KOCI, E.: Allometry of growth in small white broiler ducks. Arch. Geflügelk., 46, 1982: $162-166$

BRODY, S.: Bioenergetics and growth. New York, 1945, 1023 p.

CAMPBELL, R. G. - KARUNJEEWA, H. - BAGOT, I.: Influence of food intake and sex on the growth and carcass composition of pekin ducks. Br. Poult. Sci., 26, 1985: 43 - 50

CLAYTON, G. A. - FOXTON, R. N. - NOTT, H. - POWETC, J. C.: Est-imating carcass composition in the duck (Anas platyrhymehos). Br. Poult. Sei., 15, 1974: $153-158$ 
ClAYTON, G. A. - POWELL, J. C.: Growth, food conversion, carcass yield and their heritability in ducks (Anas platyrhynchos). Br. Poult. Sci., 20, 1979: 121 - 127

CONWAY, E. J.: Microdiffusion analysis and volumetric error. London 1957, $465 \mathrm{p}$.

EVANS, A. J.: Fat accretion during postembryonic growth in the domestic duck, with additional data from the mallard. Physiol. Z0o1., 45, 1972: 167 - 177

GARROW, J. S.: Energy stores in man, their composition and measurement. Proc. Nutr. Soc., 41, 1982: 175 - 181

HOLUB, A. - BARANYIOVA, E. - PONfŽILOVÁ, E.: Věkové změny množstvi energie $\checkmark$ těle kachen v postinkubačnim obdobi. Čs. fysiol., 36, 1978: 179

HOLUB, A. - PONIŽILOVA, E. - BARANYIOVÁ, E.: Chemical composition and energy content of duck feathers in the post-hatching period. Acta vet. Brno, 57, 1988: 99 - 109

HUDSKÝ, Z. - MACH人́LER, E.: Jatečná užitkovost kachen ve vztahu ke genotypu a výživě. Project report, Výzkumný ústav živocišné výroby Praha 10 Uhřiněves, 1978: $59 \mathrm{p}$.

KAISLER, B. - HLUBOCKÁ, E.: Komplexní zpráva z IX. mezinárodniho testu rodičovských forem kachen. Mezinárodni kontrolni stanice kachen. Ústrašice 1985a, $18 \mathrm{p}$.

KAISLER, B. - HLUBOCKA, E.: Vyhodnoceni II. dílčiho výkrmového testu kachen od IX. mezinárodního testu rodičovských forem kachen. Mezinárodni kontrolni stanice kachen. Ustrašice $1985 \mathrm{~b}, 8 \mathrm{p}$.

KIRKWOOD, K. J. K. - WEBSTER, A. J. F.: Energy-budget strategies for growth in mammals and birds. Anim. Prod., 38, 1984: 147 - 156

KOCI, E. - BAUMGARTIER, J. - ILLES, V. - PALANSKÁ, O.: Carcass and nutritive value of the Small White broiler duck and its crosses. Arch. Geflügelk., 46, 1982: $157-161$

KUHLMANN, F.: Some preliminary observations on the development of instincts and habits of young birds. Psych. Rev. Mob. Mon. Supp1., 11, 1909: 49 $-85$

LECLLERQ, B. - de CARVILLE, H.: Influence of the protein and energy contents of the diet on the growth of young muscovy ducklings. Arch. Geflügelk., 40, 1976: 117 - 119

LEESON, S. - SUMMERS, J. D. - PROULX, J.: Production and carcass characteristics of the ducks. Poultry Sci., 61, 1982: $2456-2464$

MAHITKA, B.: Přispěvek $k$ poznáni postnatálniho rústu a vývoje pekingské kachny. Sb. VSZ Brno A, 12, 1964: 323 - 330

MAHIIKA, B.: Zum Vergleich des postnatalen Wachstums und der Entwicklung der Wild- und Hausente. Acta Sci. nat. Brno, I, 1973; 1 - 50

MONTEMURRO, D. G. - STEVENSON, A. F.: Survival and body composition of normal and hypothalamic obese rats in acute starvation. Amer. J. Physio1., 198, 1960: 757 - 761

NICE, M. M.: Studies in the life history of the Song Sparrow. II. The behavior of the Song Sparrow and other passerines. Trans. Linn. Soc. N. Y., 6, 1943: 1 - 328

NICE, M. M.: Development of behavior in precocial birds. Trans. Linn. Soc. N. Y., $8,1962: 1-211$

ON 466541 Výkrm kachñat. Praha 1979, 27 p. 
PINGEL, H. - BOCH, M. - SCHEITZER, W. - MERTENS, H.: Untersuchungen über die Mast- und Schlachtleistung von Pekinenten und die Möglichkeit zur Erhöhung ihres Brustfleischansatzes. Arch. Geflügelzucht Kleintierk., 18, 1969: $151-168$

RICKLEFS, R. E.: Energetics of reproduction in birds. Pub1. Nuttall Ornitho1. Club, 15, 1974: 152 - 292

RICKLEFS, R. E.: Adaptation, constraint and compromise in avian postnatal development. Biol. Rev., 54, 1979: $269-290$

RICKLEFS, R. E.: Avian postnatal development. In Farner, D. S. - King, J. R. - Parkes, K. C.: Avian Biology, Vol. VII, Academic Press, New York - London, 1983, pp. 1 - 83

SIREGAR, A. P. - FARRELL, D. J.: A comparison of the energy and nitrogen metabolism of starved ducklings and chickens. Br. Poult. Sci., 21, 1980a: $203-211$

SIREGAR, A. P. - FARRELL, D. J.: A comparison of the energy and nitrogen metabolism of fed ducklings and chickens. Br. Poult. Sci., 21, 1980b: $213-227$

SWATLAND, H. J.: Development of carcass shape in Pekin and Muscovy ducks. Poultry Sci., 59, 1980a: 1773 - 1776

SWATLAND, H. J.: Analysis of growth in a complex muscle (m. supracoracoideus, Anas platyrhynchos). Growth, 44, 1980b: 139 - 146

SWATLAND, H. J.: Volumetric growth of muscle fibers in ducks. Growth, 44, 1980c: $355-362$

SWATLAND, H. J.: Allometric growth of histochemical types of muscle fibers in ducks. Growth, 45, 1981: $58-65$

Requests for reprints: Dr. Eva Baranyiová, Department of Physiology, University of Veterinary Science, Palackého 1-3,612 42 Brno Czechos lovakia 